\title{
Electrochemical reduction of nickel ions from dilute solutions
}

\author{
K. N. NJAU, L. J. J. JANSSEN \\ Eindhoven University of Technology, Department of Chemical Engineering, Laboratory of Instrumental Analysis, \\ PO Box 513, 5600 MB Eindhoven, The Netherlands
}

Received 8 January 1995; revised 10 April 1995

Electrochemical reduction of nickel ions in dilute solution using a divided GBC-cell is of interest for purification of waste waters. A typical solution to be treated is the effluent from steel etching processes which contain low quantities of nickel, chromate and chromium ions. Reduction of chromate in a divided GBC-cell results in effluent containing $\mathrm{Cr}^{3+}$ ions. This paper examines the limitations to further treatment of the effluent by electrochemical reduction of nickel ions. Nickel current efficiency has been determined by varying temperature, $\mathrm{pH}$, current density and concentration of supporting electrolyte. It was found that the presence of a complexing agent, e.g. $\mathrm{NH}_{4}^{+}$is necessary. To deposit nickel, complete removal of $\mathrm{Cr}^{3+}$ ions from the solution is inevitable. Optimum nickel current efficiencies are obtained at $\mathrm{pH} 5$ and current density $10 \mathrm{~mA} \mathrm{~cm}^{-2}$.

\section{Introduction}

Effluent from steel etching processes is known to contain substantial amounts of various ions, for instance chromate, nickel and cobalt ions. The presence of these metals in the effluent is a cause of major environmental concern. Treatment of such effluents requires either partial or complete removal of these constituents. Chromate is usually removed by reducing to $\mathrm{Cr}^{3+}$.

Conventionally, a reductant such as $\mathrm{Fe}^{2+}$ is added to the system in which it is oxidized, while the chromate is reduced: As environmental concerns become more stringent, requirements for even cleaner technologies for treating the effluent have become necessary. One possible device is the undivided gas diffusion electrode packed bed electrode-cell (GBC-cell) which can be used to treat chromate using hydrogen [1]

Nickel can be reduced electrolytically to metallic nickel where formation of hydrogen is a side product. Although there are other methods by which nickel can be removed, electrodeposition is attractive because the metal ion can be recycled in one step.

Nickel ions, however, cannot be reduced from their +2 oxidation state to 0 in the undivided GBC-cell with hydrogen feed as used for chromium ions. Reduction of nickel ions may be done in a divided GBC-cell with hydrogen on the hydrophobic side of a gas diffusion electrode using an external current source between the hydrogen gas diffusion electrode and the packed bed electrode.

The presence of different ions in the system can cause special problems in the reduction process and subsequent deposition of nickel. To use the divided GBC-cell for nickel deposition from an industrial process solution, it is necessary to determine the effect of different ions on the current efficiency for nickel deposition.
Reduction of nickel ions from dilute solution is reported to be highly dependent on the $\mathrm{pH}$. At low $\mathrm{pH}$ hydrogen tends to be evolved because of the small hydrogen evolution overpotential. When the $\mathrm{pH}$ of the bath is increased the equilibrium potential is displaced sufficiently to enable nickel to deposit [2]. However, as $\mathrm{pH}$ increases the formation of hydroxide on the electrode surface caused by high $\mathrm{pH}$ in the solution adjacent to the surface becomes significant. In normal practice recovery of nickel from dilute solution employs boric acid which acts as a buffer, to solve the problem of local $\mathrm{pH}$ [3].

The presence of $\mathrm{Cr}^{3+}$ is reported to drastically reduce the current efficiency for nickel deposition [3]. The formation of a film on the cathode surface due to electroreduction of chromate has been found to suppress cathodic reduction of $\mathrm{ClO}^{-}, \mathrm{Fe}(\mathrm{CN})_{6}^{3-}$ and $\mathrm{O}_{2}(\mathrm{aq})$ while hydrogen evolution remains largely unaffected. This is explained by formation of a $\mathrm{Cr}(\mathrm{OH})_{3} . x \mathrm{H}_{2} \mathrm{O}$ film which is permeable to hydrogen ions but impermeable to some other species $[4,5]$.

The present study looks into the conditions necessary for reduction of nickel ions in a divided GBCcell. These conditions will shed light on the limitations of this method, especially considering that the intention is to treat waste waters.

\section{Experimental details}

Deposition of nickel from dilute solutions was investigated using a three-electrode cell system with a graphite rotating disc electrode (RDE) of $0.50 \mathrm{~cm}^{-2}$ geometric surface area, a platinum foil counter electrode of $4 \mathrm{~cm}^{-2}$ surface area and a saturated calomel reference electrode with a Luggin capillary. Potentiostatic and galvanostatic experiments were conducted using an automatic data acquisition system (Autolab PGSTAT20 
version 3.0, Eco Chemie B.V.). All potentials were measured with reference to the saturated calomel electrode with no corrections for solution ohmic drop. Solutions with nickel sulphate concentration of $5 \mathrm{~mm}$ were made. Unless otherwise mentioned, ammonium sulphate was added to the nickel sulphate solution as a supporting electrolyte and $\mathrm{pH}$ adjuster. The effect of $\mathrm{Cr}^{3+}$ was investigated by adding $\mathrm{CrK}\left(\mathrm{SO}_{4}\right)_{2}$. Before each experiment nitrogen was bubbled through the solution for $20 \mathrm{~min}$ to remove oxygen. An atmosphere of nitrogen was maintained over the solution.

During cyclic voltammetric experiments, the working electrode was maintained at a rotation speed of $25 \mathrm{rps}$. A scan rate of $1.5 \mathrm{mV} \mathrm{s}^{-1}$ was used. The surface of the working electrode was mechanically polished and degreased before each experiment.

The effect of current, concentration of ammonium sulphate, temperature and concentration of chromium ions on current efficiency for nickel deposition was experimentally investigated. Experiments to determine the nickel current efficiency were done by galvanostatically depositing nickel, thereafter coulometrically dissolving the deposit anodically in another solution. To prevent possible passivation, a bath consisting of $0.1 \mathrm{M} \mathrm{H}_{2} \mathrm{SO}_{4}$ and $1.0 \mathrm{M} \mathrm{NaCl}$ was used during the anodic dissolution of nickel.

The nickel current efficiency $\eta_{\mathrm{CE}}$ was calculated by

$$
\eta_{\mathrm{CE}}=\frac{Q_{\mathrm{a}}}{Q_{\mathrm{c}}} \times 100
$$

where $\eta_{\mathrm{CE}}$ is the nickel current efficiency, $Q_{\mathrm{a}}$ the charge for stripping of nickel $(\mathrm{C})$ and $Q_{\mathrm{c}}$ the charge during deposition (C).

\section{Results}

\subsection{Cyclic voltammograms}

A typical voltammogram for a graphite electrode in dilute nickel sulphate solution is shown in Fig. 1. The potential was swept from $+0.0 \mathrm{~V}$ to $-1.5 \mathrm{~V}$ and back. The forward scan shows a current wave in the potential range from $-0.6 \mathrm{~V}$ to $-0.9 \mathrm{~V}$ which is caused by nickel deposition. At more cathodic potentials, the current increases rapidly and hydrogen evolution becomes significant. The voltammogram shows a clear hysteresis due to a greater overpotential required to nucleate and grow nickel on graphite compared to its deposition on nickel.

A typical voltammogram for a graphite electrode covered with a nickel layer, in a dilute nickel sulphate solution is shown on Fig. 2. This voltammogram shows clearer waves and a smaller hysteresis than that of Fig. 1. The forward scan in Fig. 2 shows a nickel reduction wave in the potential range from -0.4 to $-0.7 \mathrm{~V}$ and an additional wave from -0.75 to $-1.15 \mathrm{~V}$. This reduction wave may be related to inhibition arising from the predominance of secondary reactions [6].

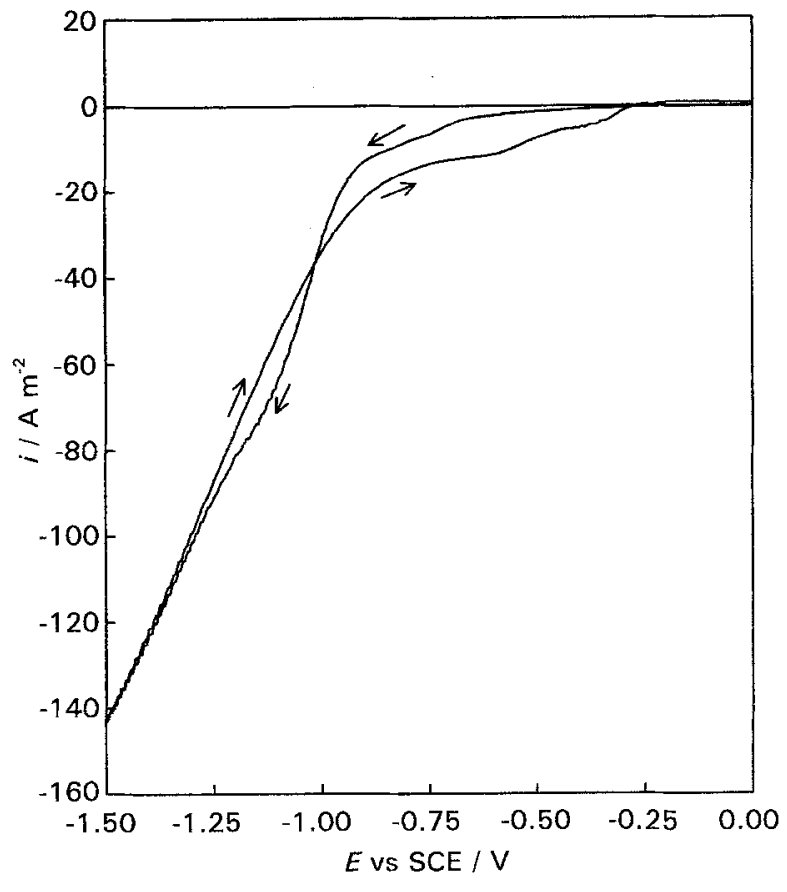

Fig. 1. Relation between current density and potential for rotating disc graphite electrode in a solution containing $5 \mathrm{mM} \mathrm{NiSO}_{4}$ and $30 \mathrm{mM}\left(\mathrm{NH}_{4}\right)_{2} \mathrm{SO}_{4}$. Potential scan rate: $1.5 \mathrm{mVs}^{-1}$, rotating speed: $25 \mathrm{rps}$ and temperature of $293 \mathrm{~K}$.

\section{2. $p H$ and nature of supporting electrolyte}

A solution of $5.0 \mathrm{~mm}$ nickel sulphate in $1 \mathrm{M} \mathrm{H}_{2} \mathrm{SO}_{4}$ was used. The $\mathrm{pH}$ of the solution was raised either by using $\mathrm{NaOH}, \mathrm{NH}_{4} \mathrm{OH}$ or both. When the $\mathrm{pH}$ was increased stepwise from about 0 to 7 using only $\mathrm{NaOH}$ it was not possible to deposit nickel at any $\mathrm{pH}$ and potential. A $\mathrm{Ni}(\mathrm{OH})_{2}$ precipitate was observed on the electrode surface beginning at a $\mathrm{pH}$

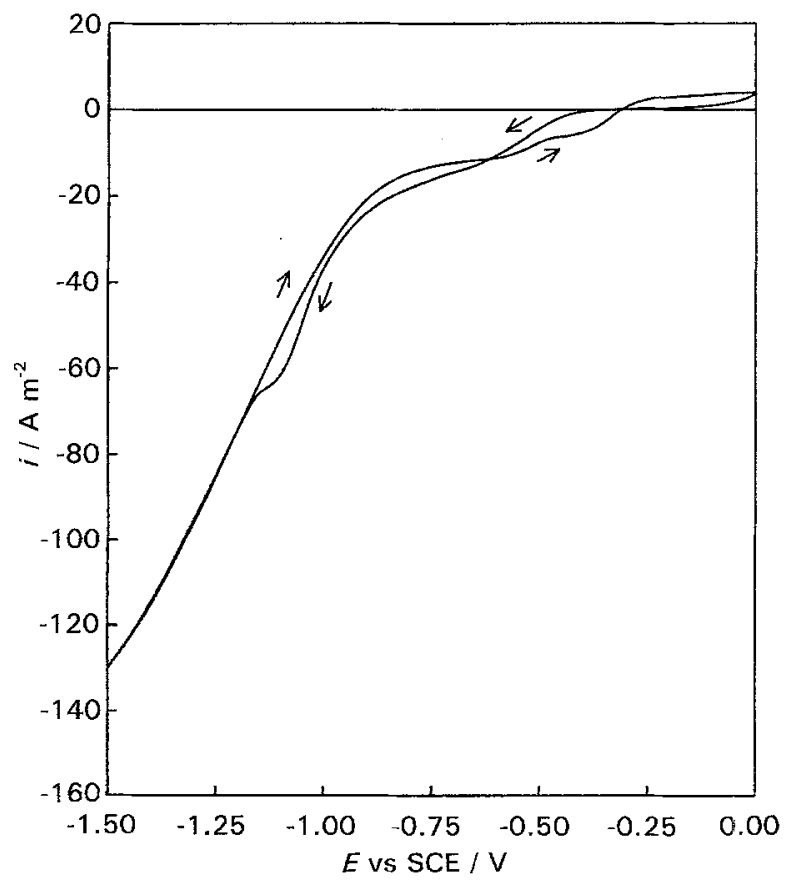

Fig. 2. Relation between current density and potential for rotating disc graphite electrode covered with a nickel layer of about $15 \mu \mathrm{m}$ thickness in a solution containing $5 \mathrm{~mm} \mathrm{NiSO}_{4}$ and $30 \mathrm{~mm}$ $\left(\mathrm{NH}_{4}\right)_{2} \mathrm{SO}_{4}$. Potential scan rate: $1.5 \mathrm{mV} \mathrm{s}^{-1}$, rotating speed: $25 \mathrm{rps}$ and temperature of $293 \mathrm{~K}$. 
of about 5.0. However, use of $\mathrm{NH}_{4} \mathrm{OH}$ made it possible to experiment with high $\mathrm{pH}$ values up to 9.0 without deposition of $\mathrm{Ni}(\mathrm{OH})_{2}$. Nickel depositions were obtained in the $\mathrm{pH}$ range from 5 to 7 . These deposits were smooth and shiny. When using a solution containing $\left(\mathrm{NH}_{4}\right)_{2} \mathrm{SO}_{4}, \mathrm{H}_{2} \mathrm{SO}_{4}$ and $\mathrm{NiSO}_{4}$ with the $\mathrm{pH}$ adjusted by addition of $\mathrm{NaOH}$ it was possible to deposit nickel in the $\mathrm{pH}$ range 3-8; however, the deposits were dull. At high $\mathrm{pH}$ the deposit was dark greyish while it became lighter as the $\mathrm{pH}$ was lower. These experiments indicate the importance of $\mathrm{NH}_{3}$ or $\mathrm{NH}_{4}^{+}$ for electrodeposition of nickel from dilute solutions.

\subsection{Current efficiency}

The rotation speed of the working electrode affects the transport processes within the system. When rotation speed was increased from 25 to $60 \mathrm{rps}$ the current efficiency increased by $7 \%$ from $63.3 \%$ to $67.7 \%$. This increase is much less than would be expected from increased mass transfer, i.e. 55\%. The mass transfer coefficient is enhanced by an increased rotation speed but diminished by an increase in the rate of gas evolution.

The dependence of nickel current efficiency on the bulk solution pH is shown in Fig. 3. The efficiency goes through a maximum at about $\mathrm{pH}$ of 5 . Both the nickel and hydrogen reactions are essentially diffusion controlled. As the $\mathrm{pH}$ of solution increases the concentration of hydrogen ions is lowered thus reducing the hydrogen current. Above a $\mathrm{pH}$ of 5 transition from $\mathrm{H}^{+}$reduction to water molecule reduction at increasing $\mathrm{pH}$ occurs; moreover, formation of stable $\mathrm{Ni}^{2+}-\mathrm{NH}_{3}$ complexes in the solution and probable formation of nickel hydroxide components on the electrode surface become significant, thus lowering the nickel current efficiency.

The dependence of nickel current efficiency on the current density is shown in Fig. 4. A maximum is

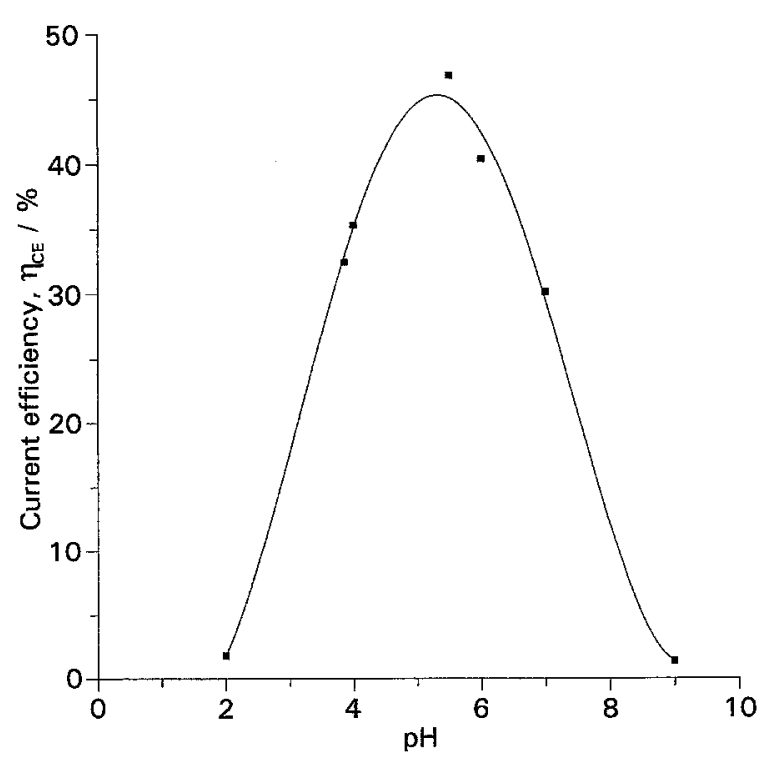

Fig. 3. Effect of $\mathrm{pH}$ of bulk solution on the nickel current efficiency. Current density: $10 \mathrm{~mA} \mathrm{~cm}^{-2}$; bath temperature: $293 \mathrm{~K}$; concentration of $\left(\mathrm{NH}_{4}\right)_{2} \mathrm{SO}_{4}=30 \mathrm{~mm}$.

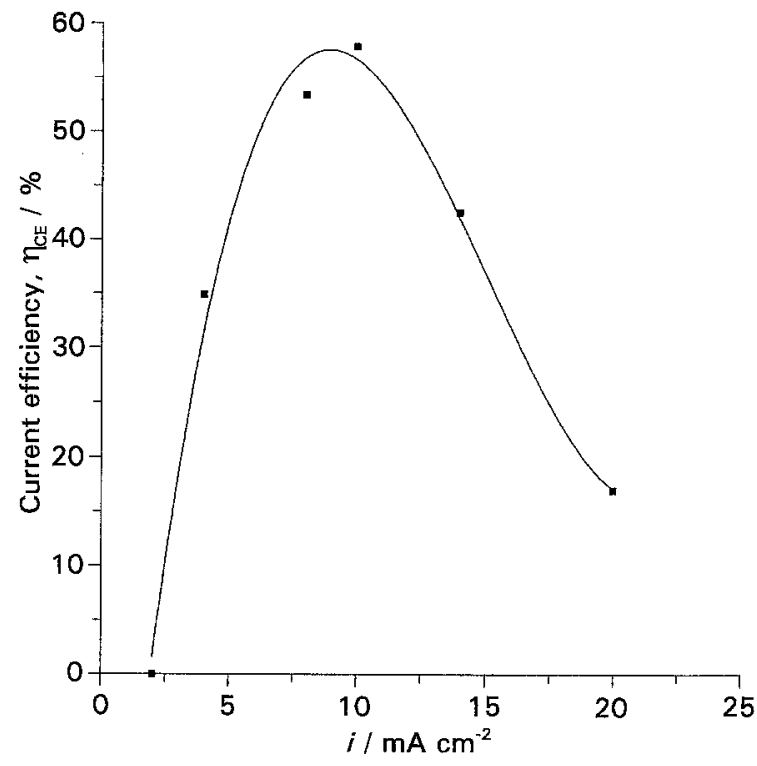

Fig. 4. Variation of nickel current efficiency with current density. Bath temperature: $293 \mathrm{~K} ; \mathrm{pH}$ (bulk solution) 5.2 ; concentration of $\left(\mathrm{NH}_{4}\right)_{2} \mathrm{SO}_{4}: 30 \mathrm{~mm}$.

attained at around $10 \mathrm{~mA} \mathrm{~cm}^{-2}$. As the current density increases hydrogen evolution becomes more significant and thus the nickel current efficiency declines.

The effect of temperature on nickel current efficiency is shown in Fig. 5. The current efficiency increases steadily up to an optimum temperature of $323 \mathrm{~K}$. Increase in bath temperature results in the following effects:

(i) Increase in conductivity of the electrolyte.

(ii) Increase in diffusivity of nickel and hydrogen ions, thus increasing the mass transfer coefficients.

(iii) Increase in rate of charge transfer processes associated with both the hydrogen reaction and nickel deposition, which leads to lower activation polarization.

(iv) Changes in the equilibrium potential of the reacting species.

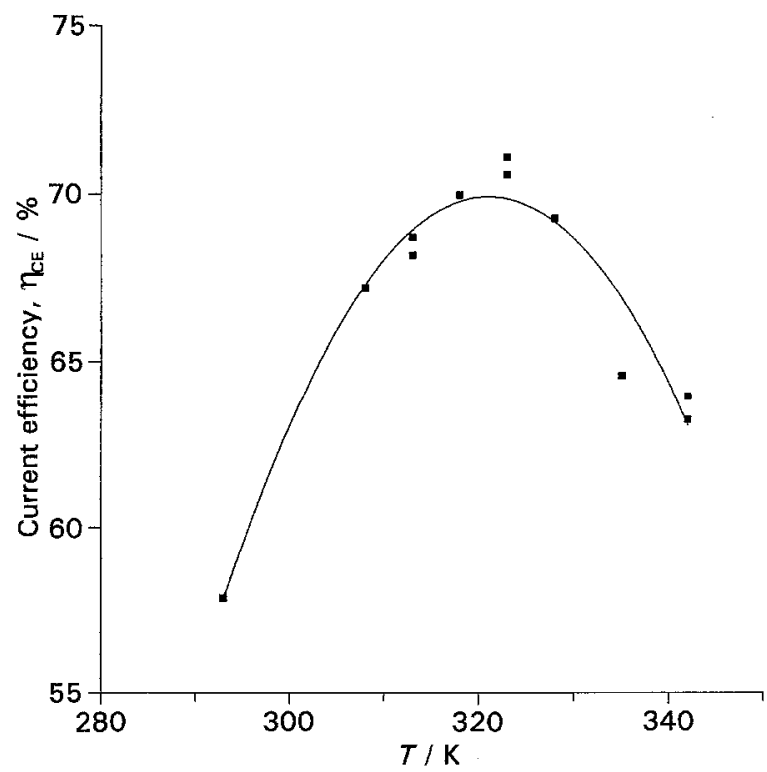

Fig. 5. Effect of temperature on the nickel current efficiency. Current density: $10 \mathrm{~mA} \mathrm{~cm}^{-2}$; concentration of $\left(\mathrm{NH}_{4}\right)_{2} \mathrm{SO}_{4}: 30 \mathrm{mM}$; $\mathrm{pH}$ (bulk solution) 5.2 . 


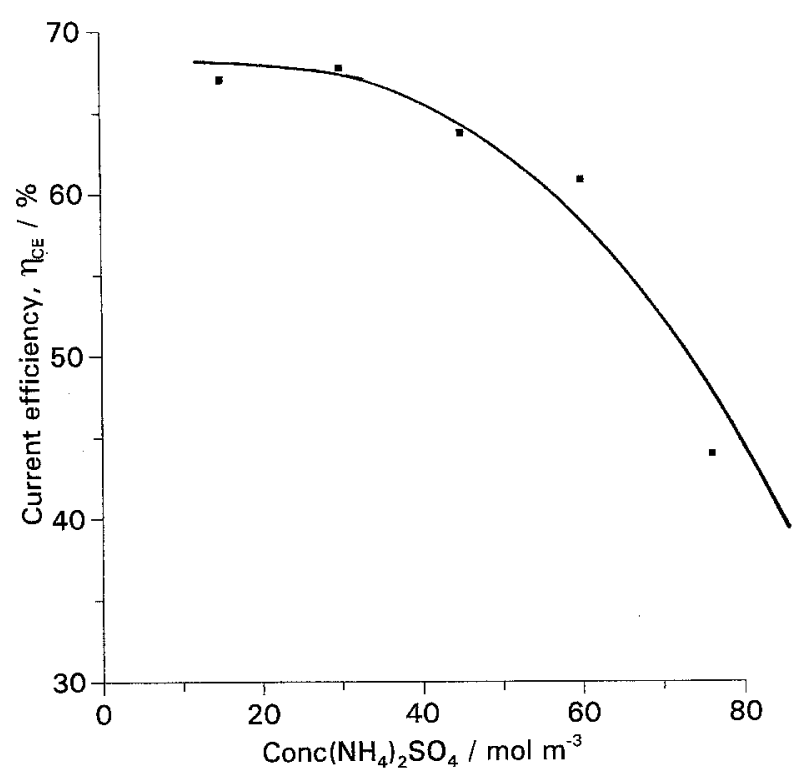

Fig. 6. Effect of concentration of $\left(\mathrm{NH}_{4}\right)_{2} \mathrm{SO}_{4}$ on the nickel current efficiency. Current density: $10 \mathrm{~mA} \mathrm{~cm}^{-2}$; bath temperature: $303 \mathrm{~K}$; pH (bulk solution) 5.2 .

Concentrations of both $\mathrm{H}^{+}$and $\mathrm{Ni}^{2+}$ are very low under the experimental conditions and thus their reactions are essentially mass transfer controlled. In this case the effect of temperature is more due to (ii). The relative effect on the two reactions depends mainly on the relative increase of diffusion coefficients with temperature. At high temperatures, however, there is a possibility of change in the nature and the size of the gas bubbles attached to the electrode surface due to the increase in the water vapour content of the gas bubbles. This may in effect result in a smaller mass transfer coefficient for transport of $\mathrm{Ni}^{2+}$ to the electrode surface.

Dependence of current efficiency on the concentration of $\left(\mathrm{NH}_{4}\right)_{2} \mathrm{SO}_{4}$ is shown in Fig. 6. The nickel current efficiency decreases at $\left(\mathrm{NH}_{4}\right)_{2} \mathrm{SO}_{4}$ concentrations higher than about $30 \mathrm{~mm}$ due to the formation of stable nickel ammonium complexes.

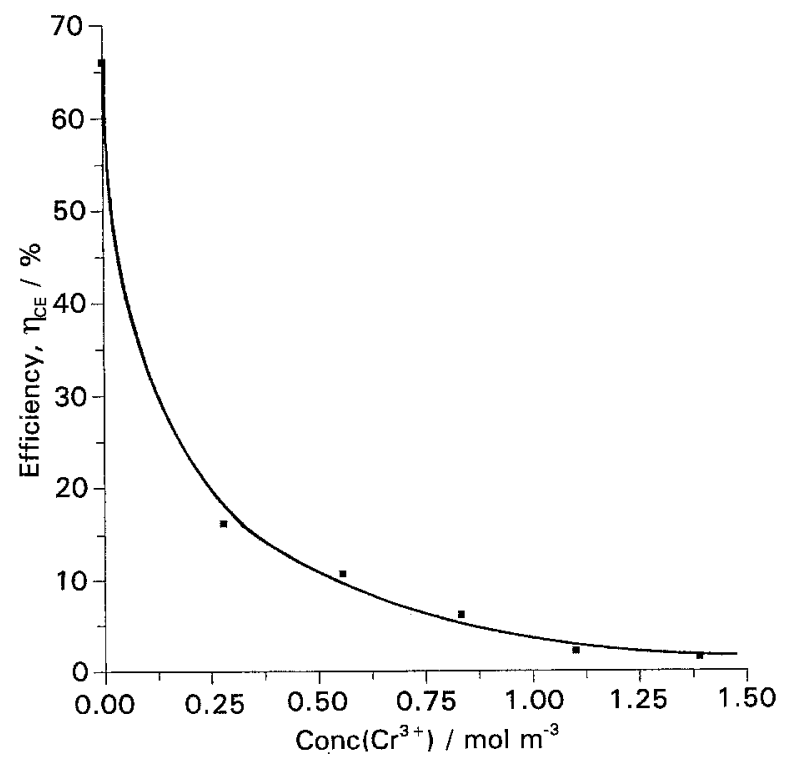

Fig. 7. Variation of nickel current efficiency with concentration of $\mathrm{Cr}^{3+}$ in the bath. Current density: $10 \mathrm{~mA} \mathrm{~cm}^{-2}$; bath temperature: $320 \mathrm{~K} ; \mathrm{pH}$ (bulk solution) 5.2; concentration of $\left(\mathrm{NH}_{4}\right)_{2} \mathrm{SO}_{4}: 30 \mathrm{mM}$.
The presence of $\mathrm{Cr}^{3+}$ ions has a drastic influence on the current efficiency. Even with only $0.3 \mathrm{mM} \mathrm{Cr}^{3+}$ in the system the efficiency drops to a mere $16 \%$ (Fig. 7). Visual inspection of the electrode surface showed a layer of precipitate, probably consisting of chromium hydroxide.

\section{Discussion}

From the results it follows that electrochemical recovery of nickel from dilute solutions requires the introduction of buffering and complexing agents. The overpotential of hydrogen evolution on nickel is small; hydrogen thus tends to be evolved, particularly in low $\mathrm{pH}$ solutions. When the $\mathrm{pH}$ of the bath is increased the equilibrium potential is displaced sufficiently to enable nickel to deposit.

Introduction of ammonia has been found to be necessary in the system studied, due to its property as a complexing agent with nickel ions. Experiments have indicated that $\mathrm{Ni}(\mathrm{OH})_{2}$ precipitation does not occur at $\mathrm{pH}$ below 11 when the solution contains $0.15 \mathrm{M} \mathrm{NH} 3$ and $\mathrm{NH}_{4}^{+}$. In the presence of $\mathrm{NaOH}$ exclusively, $\mathrm{Ni}(\mathrm{OH})_{2}$ precipitation occurs at $\mathrm{pH}>8$. The importance of ammonia can be explained on the basis of the formation of nickel ammonia complexes [7].

As electrodeposition proceeds the $\mathrm{pH}$ at the electrode surface becomes higher than that in the bulk solution due to hydrogen formation, which consumes $\mathrm{H}^{+}$ions. Thus that the formation of $\mathrm{Ni}^{2+}$ complexes with $\mathrm{NH}_{3}, \mathrm{H}_{2} \mathrm{O}$ and $\mathrm{OH}^{-}$is promoted near the electrode surface and the formation of $\mathrm{Ni}(\mathrm{OH})_{2}$ deposit on the electrode surface is hindered. At high ammonium concentration the current efficiency declines. This decline may be caused by the formation of stable nickel ammonium complexes.

Use of a packed bed would be very attractive to the electrochemical recovery of nickel from dilute solutions because of the large ratio between the electrode surface area and the volume of the bed. Carbon offers a cheap packing material. Moreover, the deposition of nickel on graphite requires a higher nucleation overpotential than on nickel. This means that deposition of nickel aggregates is possible. When graphite was used a nucleation overpotential of about $0.3 \mathrm{~V}$ was observed.

Electrochemical deposition of nickel is necessarily a low current efficiency process. In these experiments a maximum nickel current efficiency of $71 \%$ was observed. There is a strong dependence of current efficiency on current density. The presence of $\mathrm{Cr}^{3+}$ ions has a drastic effect in the deposition process. This means that complete removal of $\mathrm{Cr}^{3+}$ is necessary prior to nickel deposition.

The results show that the deposition of nickel from dilute solution without the presence of chromium ions in a packed bed of graphite particles is possible. However, the electrolysis conditions must be carefully chosen. Further experiments with a packed bed electrode will be carried out. 


\section{References}

[1] E. C. W. Wijnbelt and L. J. J. Janssen, J. Appl. Electrochem. 24 (1994) 1028.

[2] A. T. Kuhn, 'Industrial electrochemical processes', Elsevier Publishing, Amsterdam (1971).

[3] B. D. Barker and B. A. Plunkett, Trans. Inst. Met. Finish. 54 (1976) 104.
[4] G. Lindbergh and D. Simonsson, Electrochim. Acta 36 (1991) 198.

[5] A. Cornell, G. Lindbergh and D. Simonsson, ibid. 37 (1992) 1873.

[6] E. Valles, R. Pollina and E. Gomez, J. Appl. Elecrochem. 23 (1993) 508.

[7] F. A. Lowenheim, 'Modern electroplating' John Wiley \& Sons, New York (1974). 